The Lancet Infectious Diseases Published Online August 10, 2016

DOI: http://dx.doi.org/10.1016/S1473-3099(16)30119-0

http://www.thelancet.com/journals/laninf/article/PIIS1473-3099(16)30119-0/fulltext

\title{
Plagued by Doubt and Viral Misinformation: The Need for Evidence-based Use of Historical Disease Images
}

\author{
Lori Jones and Richard Nevell
}

The Lancet Infectious Diseases Published Online August 10, 2016

DOI: http://dx.doi.org/10.1016/S1473-3099(16)30119-0

http://www.thelancet.com/journals/laninf/article/PIIS1473-3099(16)30119-0/fulltext

\begin{abstract}
The digitisation of historical disease images and their widespread availability on the internet have been a boon to education and research, but with unintended consequences, including the misrepresentation of infectious diseases in the past and the viral spread of misinformation. Many medieval images containing scenes of infectious disease come from nonmedical sources and are not meant to convey any medical meaning. Erroneous modern captions have led to the publication of several historical images labelled as depictions of the plague, although artistic and textual evidence shows that they are not. Mislabelled images lose their intended historical narrative, and their use creates a distorted view of the past and of the disease in question. Scholars should give the same careful consideration to an image's evidentiary context that they would insist on giving to all other forms of evidence.
\end{abstract}

Medical education literature accepts that the evidentiary use of images enhances the teaching and publication of research on historical infectious diseases. ${ }^{1-3}$ Visual representations of microscopic pathogens, their modes of transmission, and their symptoms give students and readers a better understanding of diseases. Visualisations of people's responses to epidemics throughout history also reveal the personal effects of infectious disease. Images highlight the reality that disease is more than a biological event; it also has sociocultural, political, intellectual, and institutional identities and consequences. ${ }^{4}$

Thanks to multiple digitisation projects - and the reposting of digitised images online - scholars now have access to a greater variety and number of historical disease images than they ever have before. A quick search generates a plethora of images from all periods. Illustration of texts and presentations with engaging images of infectious diseases has never been simpler. Although improved access to the past is clearly a boon to education and research - and to the generation of public interest in the science of disease - it has unintended consequences. One key drawback is the occasional abrogation of the rigorous standards of evidence and interpretation that scholars otherwise expect within their own disciplines, which can result in an exponential spread of misinformation. This problem is not limited to images, of course: scholars regularly chastise colleagues in other disciplines for misrepresenting their evidence-eg, historical texts, scientific data, clinical results - to make arguments that such material cannot support in its original context. Even for cases in which corroborating microscopic evidence exists, care should be taken to avoid the imposition of modern disease assumptions onto historical images. ${ }^{5,6}$ The original meanings behind digitised, cropped, and decontextualised historical images are often lost. Seemingly mundane actions, such as inaccurate modern captioning, can change an image's meaning into something that it was never meant to represent. Artistic conventions change over time, and both writers and artists describe the diseases that they portray through experiences that 
The Lancet Infectious Diseases Published Online August 10, 2016

DOI: http://dx.doi.org/10.1016/S1473-3099(16)30119-0

http://www.thelancet.com/journals/laninf/article/PIIS1473-3099(16)30119-0/fulltext

are specific to particular times and places. ${ }^{7}$ The context in which images first appear is vital: many medieval images of infectious disease, for example, come from non-medical sources (ie, chronicles or religious works) that have no ostensible medical pedagogical or clinical function, ${ }^{8}$ thus providing no explicit reason to label that disease in medical terms.

We present three short case studies of ongoing efforts to rectify the misuse of historical images erroneously labelled as the plague. The human toll of the Black Death of 1346-53 was devastating. The public sees the plague as a visible symbol of the medieval era, and the disease is a popular teaching and research topic. In this Personal View we address the importance of multidisciplinary work in the interpretation of the evidence provided by historical disease images, ${ }^{9}$ and the question of what scholars should expect from such images. Although we focus on historical images of the plague, the lessons and cautions raised here are equally valid for representations and misrepresentations of other historical diseases.

\section{Case Studies}

\section{Omne Bonum, circa 1360-1375}

In October, 2012, Monica $\mathrm{H}$ Green posted a commentary on a medieval medicine listserv about the widespread use of a mislabelled manuscript image (figure 1). The manuscript, called the Omne Bonum, ${ }^{10}$ is a 14 th-century Latin encyclopaedia written by London clerk James le Palmer.

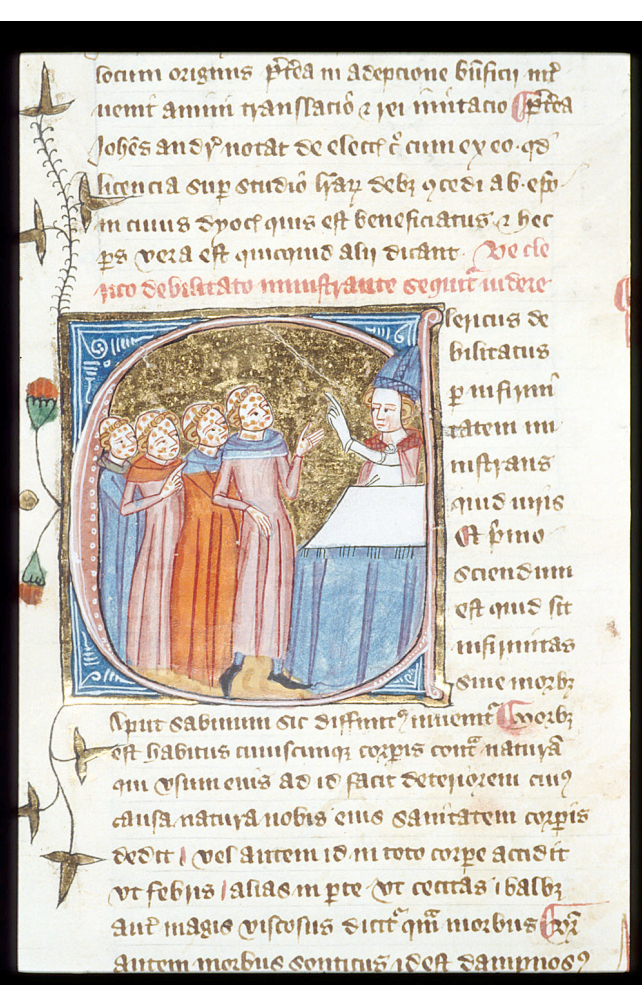

Figure 1: James le Palmer, Omne Bonum, circa 1365. Reproduced in accordance with the British Library's guidelines for the reproduction of images in the public domain ( $\mathrm{CC} 01.0)$.
In 1996, an art historian studying the manuscript identified the image as a depiction of clerics with leprosy receiving instruction from a bishop. ${ }^{11}$ This identification relied both on the surrounding textwhich speaks of the impact of illness, including leprosy, on clerics - and on medieval artistic convention, which used bodily spots to depict leprosy. ${ }^{12}$ The clerics are standing, whereas the rapidly debilitating plague would probably have left them bedridden. However, the disease shown in the image was subsequently recast as the plague. Green led a multidisciplinary collaborative investigation that uncovered a series of captioning errors - beginning with the British Library's Images Online webpage in 2006 and carried through to Wikipedia in the same year, and then to commercial stock photo websites - which effectively turned this image of leprosy into one of the world's most iconic images of medieval plague. 9 Within a few years, the image was widespread on the internet and in printed materials, cropped and stripped of its original text and

with its artistic conventions ignored. It appeared with a plague caption in science journals, ${ }^{13}$ history publications, popular and scholarly websites and documentaries, museum exhibits, magazines, tourist pamphlets, and for-profit websites. The error is understandable: the Black Death sometimes caused visible clinical symptoms, including bodily marks, and coincided roughly with the production of the Omne Bonum. Because its modern caption said that it was a plague image, it became an image of the plague, despite its textual and internal artistic evidence to the contrary. ${ }^{9}$ 
The Lancet Infectious Diseases Published Online August 10, 2016

DOI: http://dx.doi.org/10.1016/S1473-3099(16)30119-0

http://www.thelancet.com/journals/laninf/article/PIIS1473-3099(16)30119-0/fulltext

Identification of the source of the captioning error was just the first step towards its rectification. In early December, 2014, at Green's request, the British Library changed the caption in its online catalogues. ${ }^{14}$ We then led the image's removal or caption correction on 23 different language Wikipedias. This action helped to stem further dissemination (in 2014, 4.3 million viewers accessed the English Wikipedia's Black Death page). ${ }^{15}$ We requested the hosts of 51 websites using the image (educational or informational organisations focusing on science, medicine, or history, media, and commercial companies) to remove or recaption it. 22 website hosts did so; three left the image online for educational purposes, and 26 did not respond nor make any changes (including the for-profit sites). ${ }^{14}$ The British Library's reputation as a world-leading resource lends credibility to its content, and Wikipedia has become a popular information source for the public and scholars of many disciplines. ${ }^{16}$ Each time another website reproduces the mislabelled image and cites either resource as its source, the misinterpretation gains further credibility (even after the original sites had corrected the error). Unfortunately, sales of the image online also give credibility to its caption.

\section{Toggenburg Bible, circa 1411}

Our follow-up with websites using the Omne Bonum image revealed a further problem: several had replaced it with another image similarly mislabelled as medieval plague (figure 2). This

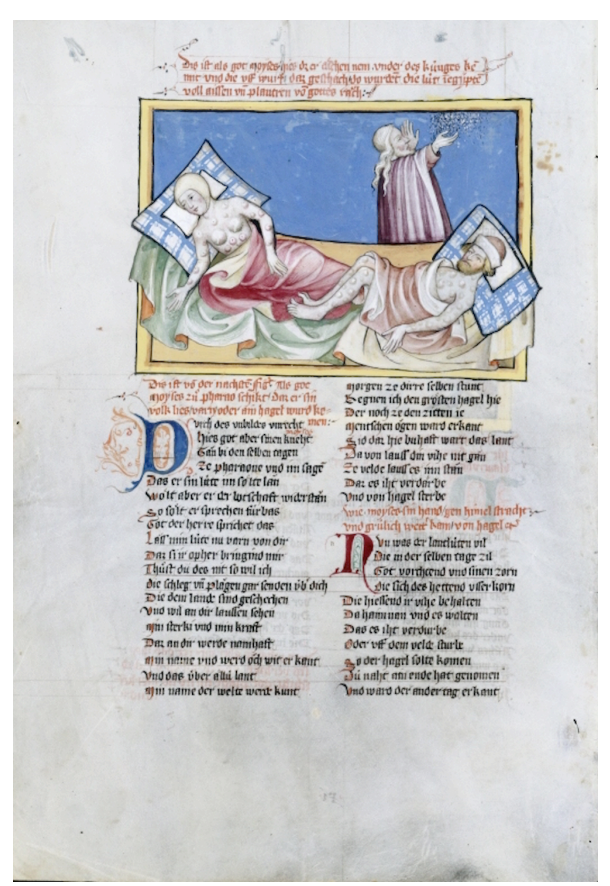

Figure 2: Toggenburg Bible, Beulenpest (Zehn Plagen, die über Ägypten kommen), circa 1411. Reproduced in accordance with the Staatliche Museen zu Berlin's guidelines for the reproduction of images in the public domain (CC BY-NC-SA 3.0 DE). second image comes from an early 15 th-century reproduction ${ }^{17}$ of Rudolf von Ems's mid-13th-century Swiss Weltchronik, a German-language world chronicle used as political propaganda by the Hohenstaufen dynasty. ${ }^{18,19}$ Around 1411, Dietrich von Lichtensteig produced a new, illustrated version of the text (popularly called the Toggenburg Bible) for Count Frederick VII of Toggenburg. ${ }^{20}$ In this version, von Ems's 13th-century text about the ten plagues of Egypt surrounds the image that now erroneously carries a Black Death caption.

Neither of the two modern scholarly studies that describe the Toggenburg Bible's images includes this illustration. ${ }^{21,22}$ The manuscript's modern holding institution introduced an error into its online caption by conflating the image of the ten plagues of Egypt with the bubonic plague (Beulenpest). That error subsequently appeared, in various permutations, on some 100 different Wikipedia pages, as well as in numerous documentaries, recent academic publications, ${ }^{23}$ and popular, scholarly, and for-profit websites. The image also appeared on the cover of an infectious disease journal in 2011, captioned "The Black Death-from the 10 Plagues of Egypt". ${ }^{24}$

Although the sixth biblical plague is the curse of festering skin boils, any attempt to link von Ems's original text to the Black Death, which occurred a century later, is clearly untenable. Like Omne bonum, however, the Toggenburg Bible appeared during an era of recurring plague outbreaks, and it contains a medieval image of ill people showing bodily marks. The text immediately above the image is an adaptation of Exodus 9: 8-9: "This is when God set Moses to take ashes from the furnace and throw them up. As that was 
done, so the people in Egypt became full of boils and sores because of God's revenge." The image's figures and action reflect this text, clearly depicting a man (Moses) throwing fine ash or soot into the air, a crowned, bedridden man (the pharaoh in Exodus), ${ }^{25}$ and people with bodily sores. What is not shown is an accurate clinical depiction of bubonic plague generally or of the Black Death specifically. The text that follows is about the hail of the seventh plague. In early 2015, we uploaded a new caption for the image on some Wikipedia pages. The website hosts we contacted removed the image. However, it remains widespread on many websites with the plague caption.

\section{La Franceschina, circa 1474}

A third image (figure 3 ) with the label "Franciscans treat plague victims" accompanied a July, 2015, BBC History Magazine article $^{26}$ on the Black Death (the magazine had used the Omne Bonum image ${ }^{27}$ in October, 2014). The illustration portrays people with widespread spots. It also includes two individuals with clappers - wooden devices used by medieval lepers to attract attention ${ }^{28}$ - and the 13th-century St Francis, whose conversion followed a chance encounter with a leper. ${ }^{29}$ An online search and consultations with historians of medicine, art, and religion revealed that the image comes from a 15 th-century manuscript, La Franceschina ${ }^{30}$ that contains a celebratory history of the Franciscan order and hagiographies of early Franciscan saints. The text's author, Jacopo or Giacomo Oddi, entered the (Franciscan) Order of Observant Friars Minor in 1448.

Examination of a modern edition of the work confirmed that text surrounding the image corresponds with chapter seven of La Franceschina, entitled De la Santa Humilità (Of the Holy Humility). ${ }^{31}$ It discusses Francis' imitation of Christ's life, in particular by caring for the poor and lepers, his determination that his followers do the same, and his conversion. It also contains descriptions of leprous wounds: tucto lacerato et habominevele ad vedere (all lacerated and abominable to see) and orribilissimament conroso et ulcerato (horribly corroded and ulcerated). The

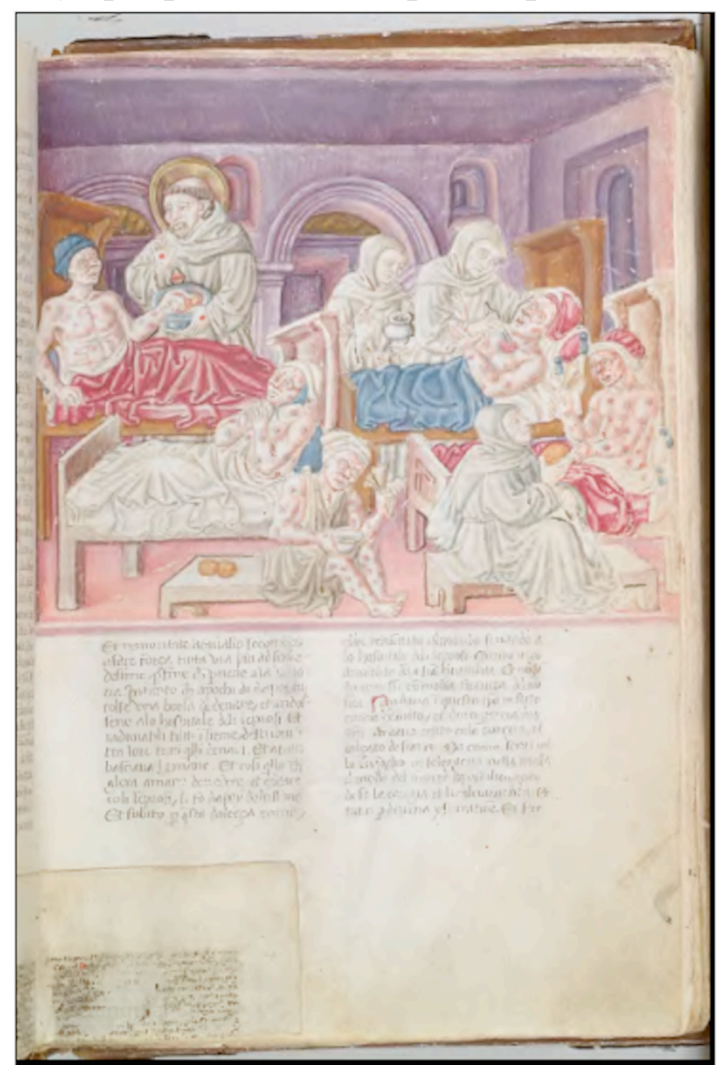

Figure 3: De la Santa Humilità, La Franceschina, circa 1474 Reproduced with permission of the Biblioteca Augusta di Perugia image likewise shows Francis and his disciples tending to people in the Santa Maria degli Angeli leper hospital. Two of the three other copies of the text include a similar image of Franciscans tending lepers in a hospital setting; all four copies contain additional images of Franciscans and lepers.

Our Google Image search revealed that in February, 2015, the popular news website Vox used the image to illustrate its story about gerbils and the Black Death (Vox had used the Omne Bonum image in an earlier plague story). ${ }^{32,33}$ As with the other two images, the La Franceschina 
The Lancet Infectious Diseases Published Online August 10, 2016

DOI: http://dx.doi.org/10.1016/S1473-3099(16)30119-0

http://www.thelancet.com/journals/laninf/article/PIIS1473-3099(16)30119-0/fulltext

image appears on several commercial websites with a plague caption. In September, 2015, the image was not widely used elsewhere on the internet. It appeared with a plague caption in Wikimedia Commons, the image database that Wikipedia contributors use to select illustrations for their articles, and on the Swedish Wikipedia's article on England in the Middle Ages. It also featured in popularised online courses about the Black Death. We added shelf mark information and an updated caption in Wikimedia Commons, along with a new filename, which should mitigate further misuse of the image. However, our requests to the commercial sites to correct their captions were unanswered and unaddressed.

When Oddi wrote La Franceschina in the late 15th century, plague outbreaks remained a recurring problem. The crowded nature of the image conveys a sense of medical urgency that might suggest the artist was not thinking only of lepers; it might therefore reflect other considerations. Nevertheless, any direct connection to the plague is unlikely, given the image's textual context and purpose.

\section{Discussion}

Each of these cases concerns a digitised, cropped, decontextualised, mislabelled, andgenerally - widely circulated image taken from a medieval manuscript. Each of these images, produced in the 14th and 15th centuries, clearly refl ects a disease scene. The evidence shows that none is an image of plague, despite modern captioning.

Such misinformation matters because without the same careful consideration given to the evidentiary context of an image that scholars would insist on giving to their own types of scientific or historical evidence (for example, ancient DNA, texts, archaeological remains), the image is given the wrong meaning and loses its historical narrative. The viewer should not assume that what they think they see in an image is what it was meant to portray. However, by reading the evidence that the image provides, and by drawing on the expertise of multiple disciplines, the viewer can get much closer to an image's intended meaning.

Most early European plague images are religious in nature, commissioned to give thanks for or to pray for spiritual and physical safety from epidemic outbreaks. ${ }^{34}$ Some portray the community-level devastation of epidemic disease on the basis of classical and biblical literary sources; others provide allegorical messages, with the plague used as a metaphor. In most cases, the plague was alluded to through metaphorical symbols of plague causing agents, such as bows and arrows, swords, and clouds. ${ }^{35}$ In only a small number of cases did artists incorporate the most recognised clinical symptoms of the bubonic manifestation of the disease: the swollen, sometimes discoloured buboes of the thigh, armpit, or neck. In fact, symptomatic images of plague are rare before the late 15 th century - after the production of the images discussed here. The relative paucity of direct visual medieval representations of the disease creates opportunity for misrepresentation. In the public imagination, the Black Death is one of the defining features of the Middle Ages, making it easy to assume that medieval depictions of any spotty illness must represent this disease.

Disease categories have never been fixed. Medical thinking and iconographic disease conventions have both changed strikingly over time. Modern germ theory-based nosology has, on one hand, fostered increased interest in retrospective diagnosis; on the other, it has led some medical historians to question the legitimacy of identification of diseases of the past. ${ }^{5,36}$ Important advances in paleogenetics and paleomicrobiology ${ }^{37}$ over the past two decades might have turned that issue on its head. Since 1998, notable achievements have increasingly 
The Lancet Infectious Diseases Published Online August 10, 2016

DOI: http://dx.doi.org/10.1016/S1473-3099(16)30119-0

http://www.thelancet.com/journals/laninf/article/PIIS1473-3099(16)30119-0/fulltext

transformed how historians approach the historical study of plague, allowing them to move onto important questions on why, how, and with what consequence the plague occurred. ${ }^{38-40}$ Since the first publication announcing ancient human dental pulp containing Yersinia pestis ancient DNA, ${ }^{41}$ scientists have reconstructed its full genome, ${ }^{42}$ reconstructed its evolutionary history, ${ }^{43}$ and suggested the potential endemicity of the plague in Europe ${ }^{44,45}$ and the Middle East, ${ }^{46}$ all of which open new historical questions. Other studies have also broadened the historical narrative in various ways: adding more whole genomes to the pool of $Y$ pestis data ${ }^{47}$ highlighting the variety of potential $Y$ pestis hosts and vectors ${ }^{48,49}$ and the role of microclimates in pathogen survival, ${ }^{50}$ exploring immunological responses, ${ }^{51}$ assessing mortality patterns,${ }^{52}$ and suggesting a potential route and impact of the plague in historical sub-Saharan Africa. ${ }^{53}$ Similar work is commencing with leprosy ${ }^{54,55}$ Scientific evidence should nevertheless be historicised just as rigorously as other forms of historical evidence. ${ }^{38,56,57}$ By confirming both the historical presence of pathogens and their evolution, scientific evidence has reinvigorated the humanist narrative of disease history. Use of science to restructure the history of disease is essential for historians to examine how people in the past experienced disease. At the same time, historical inquiries into human communities, cultures, and activities are essential for explaining how pathogens and diseases moved across time and space. ${ }^{39}$ Scientific and humanistic approaches to the history of disease thus enrich one another, but neither should use the other casually. Each has rigorous standards of what constitutes evidence and what types of interpretations of that evidence are valid. Both approaches should be respected.

The same respect should be applied to the use of historical disease images. Although iconodiagnosis - the retrospective diagnosis of diseases through art forms - has shed light on prehistoric and ancient patho physiological dysfunctions, contemporary aesthetic constraints, symbolic imagery, and iconographic traditions cannot be neglected. ${ }^{58,59}$ Disease portrayals of any sort must be seen as what they are: artistic representations set into a particular narrative context. In the case of many medieval manuscripts, neither the artists nor the texts they illustrated were meant to educate or inform health practitioners - or anyone else - about the disease being portrayed. ${ }^{8}$ The images are not, therefore, medical illustrations. Instead, an image's role was to elucidate, support, or encapsulate a particular text, and to engage the reader. An image containing a disease scene might not have been an image about clinical disease at all.

Furthermore, contemporary representations of disease need to be taken seriously before we attempt to make any other uses of, or draw any analyses from, historical images. People in the past did not think it necessary to depict the same things that modern society depicts, nor did they have the same need for visual representation. Medieval medical treatises on the plague, for example, rarely included images of the disease.

Google Images and most commercial stock photo sites are dependent on the labels applied to images as they are digitised; an initial error made during cataloguing becomes the image's identity. Correction of this error becomes even more difficult once it crosses the language barrier. When digital disease images are too eagerly copied, circulated, and used without consideration of their original historical context, an image that was meant by its creator to reflect one set of symptoms, conditions, or events can be used erroneously to illustrate discussion of another, modern-defined disease. However, careful consideration of the internal evidence- the image in the context of its accompanying text —offers a better chance of understanding what the image is meant to portray. 
The Lancet Infectious Diseases Published Online August 10, 2016

DOI: http://dx.doi.org/10.1016/S1473-3099(16)30119-0

http://www.thelancet.com/journals/laninf/article/PIIS1473-3099(16)30119-0/fulltext

How can this situation be avoided in the future? As museums and libraries digitise their collections, information is becoming rapidly democratised. Accurate metadata must be in place to ensure that these collections are properly used. To expect perfection or that experts spend time double-checking every single digitised manuscript is unreasonable. However, institutions can adopt an open approach. Projects such as Zooniverse use the vast resources of the public to process large amounts of data and recognise patterns. Through such a model, institutions and the public can work together, encouraging a flexible, but accurate, approach to information management.

Historical disease images are windows into the past, as people faced epidemics, loss, fear, and hope. Deliberately being ignorant of that past by treating it as unknowable or blindly assigning modern meaning to it is a great scholarly injustice.

\section{Acknowledgments}

We thank Monica H Green, who inspired and encouraged this study, and gave us her copious background research, and Ann G Carmichael, who reviewed the modern edition of $L a$ Franceschina and provided detailed notes from it. Both Green and Carmichael commented on earlier drafts of the article. We thank Fabian Crespo, Jack Hartnell, Catherine M Mooney, and Michelle Ziegler, all of whom contributed evidence to the unmasking of the images discussed here, and Lucy Barnhouse, who transcribed and translated the Toggenburg Bible text for us.

\section{References:}

1. Freeman LH, Bays C. Using literature and the arts to teach nursing. Int J Nurs Educ Scholarsh 2007; 4: 1377.

2. Reilly JM, Ring J, Duke L. Visual thinking strategies: a new role for art in medical education. J Fam Med 2005; 37: 250-2.

3. Dolev JC, Friedlaender LK, Braverman IM. Use of fine art to enhance visual diagnostic skills. JAMA 2001; 286:1020-1.

4. Rosenberg CE. Disease in history: frames and framers. The Milbank Quarterly 1989; 67: 1-15.

5. Cunningham A. Identifying disease in the past: cutting the Gordian Knot. Asclepio, 2002; 54: 13-34.

6. Mitchell PD. Retrospective diagnosis and the use of historical texts for investigating disease in the past. International Journal of Paleopathology 2011; 1: 81-8.

7. Muramoto O. Retrospective diagnosis of a famous historical figure: ontological, epistemic, and ethical considerations. Philos Ethics Humanit Med 2014; 9: 1-15.

8. Jones, PM. Word and image in medieval medicine. In: Givens JA, Reeds KM, MacKinney A, editors. Visualizing medieval medicine and natural history, 1200-1550. Berkeley, CA: University of California Press; 2006: 1-24.

9. Green M, Walker-Meikle K, Müller WP. Diagnosis of a 'plague' image: a digital cautionary tale. The Medieval Globe 2014; 1: 309-26.

10. British Library, London. MS Royal 6 E VI, vol 2, fol301ra. http://www.bl.uk/catalogues/illuminatedmanuscripts/ILLUMIN.ASP?Size=mid\&IllID=32116 (accessed Oct 30, 2015).

11. Sandler LF. Omne bonum: a fourteenth century encyclopedia of universal knowledge. 2 volumes. London: Harvey Miller; 1996.

12. Boeckl CM. Images of leprosy: disease, religion and politics in European art. Kirksville, MO: Truman State University Press; 2011.

13. Callaway E. The Black Death decoded. Nature 2011; 478: 444-6.

14. Jones L. Getting the words out (and back in): what to do when a plague image is not an image of plague. Available at: http://arc-medieval.blogspot.ca/2015/03/getting-words-out-and-back-in-what-to.html. Accessed 29 September 2015.

15. Nevell R. The truth gets its shoes on: the Black Death on Wikipedia. Available from: https://blog.wikimedia.org.uk/2015/01/the-truth-gets-its-shoes-on-the-black-death-on-wikipedia. Accessed 3 October 2015. 
The Lancet Infectious Diseases Published Online August 10, 2016

DOI: http://dx.doi.org/10.1016/S1473-3099(16)30119-0

http://www.thelancet.com/journals/laninf/article/PIIS1473-3099(16)30119-0/fulltext

16. Harvard Guide to Using Sources. What's wrong with Wikipedia? Available at:

http://isites.harvard.edu/icb/icb.do?keyword=k70847\&pageid=icb.page346376. Accessed 2 October 2015.

17. Staatliche Museen zu Berlin, Berlin. Ident Nr 78.E.1, fol.80v. http://www.smb-

digital.de/eMuseumPlus?service $=$ ExternalInterface\&module $=$ collection\&objectId $=819062 \&$ viewType $=$ det ailView (accessed Oct 30, 2015).

18. Gärtner K, Broszinski H. Rudolf von Ems weltchronik. Munich: Edition Helga Lengenfelder; 1989.

19. Frey W, Raitz W, Seitz D, et al. Rudolf von Ems. In: Frey W, Raitz W, Seitz D, editors. Einführung in die deutsche Literatur des 12. bis 16. Jahrhunderts: Patriziat und Landesherrschaft - 13.-15. Jahrhundert. Wiesbaden: VS Verlag für Sozialwissenschaften; 1982.

20. Dearden JS. John Ruskin, the collector: with a catalogue of the illuminated and other manuscripts formerly in his collection. The Library 1966; Series 5, 21: 124-54.

21. Anzelewsky F. Miniaturen aus der Toggenburg-Chronik aus dem jahre 1411. Baden-Baden: Woldemar Klein Verlag; 1960.

22. Anzelewsky F. Toggenburg Weltchronik: Vierundzwanzig farbige Miniaturen aus einer Chronik vom Jahr 1411. Aachen: Verlag Voldemar Klein; 1970.

23. Frankopan, P. The silk roads: a new history of the world. New York: Alfred A. Knopf; 2016.

24. Clin Infect Dis August 1 2011; 53, issue 3: cover. Oxford University Press. http://cid.oxfordjournals.org/content/53/3.cover-expansion (accessed June 28, 2016).

25. Bible Gateway. New King James Bible. Exodus 9:8-9. Available at: https://www.biblegateway.com/passage/?search=Exodus+9\%3A8-9\&version=NKJV. Accessed 28 September 2015.

26. Hodgman C. The Black Death: the historian's view. BBC History Magazine 2015; 7: 28-32.

27. Hatcher J. Q \& A .BBC History Magazine 2014; 10: 90.

28. Demaitre, L. Leprosy in premodern medicine: a malady of the whole body. Baltimore: Johns Hopkins University Press; 2007.

29. Vauchez A. Francis of Assisi: the life and afterlife of a medieval saint. Trans: Cusato MF. New Haven: Yale University Press; 2012.

30. Biblioteca Augusta di Perugia, Perugia. MS 1238, fol. 223r. http://augusta.alchimedia.com/scheda.aspx?prov=div\&ID=122 (accessed Oct 30, 2015).

31. Cavanna PN, editor. La Franceschina: testo volgare Umbro del secolo xv scritto dal P. Giacomo Oddi di Perugia. 2 volumes. Florence: Leo S. Olschki; 1931.

32. Plumer B. Scientists now suspect gerbils were the real villains in the Black Death. Vox Science and Health 24 February 2015. Available at: http://www.vox.com/2015/2/24/8101329/black-death-gerbils-rats. Accessed 30 September 2015.

33. Kurtzleben D. 13 women explain why they date men with the Bubonic Plague. Vox Topics 8 October 2014. Available at: http://www.vox.com/2014/10/8/6946367/time-date-women-over-30-date-men-with-bubonicplague-black-death. Accessed 30 September 2015.

34. Boeckl CM. Images of plague and pestilence: iconography and iconology. Kirksville, Missouri: Truman State University Press; 2000.

35. Boeckl CM. Giorgio Vasari's 'San Rocco Altarpiece': tradition and innovation in plague iconography. Artibus et Historiae 2001; 22: 29-40.

36. Arrizabalaga J. Problematizing retrospective diagnosis in the history of disease. Asclepio 2002; 1: 51-70.

37. Raoult D, Drancourt M., editors. Paleomicrobiology: past human infections. Berlin: Springer, 2005.

38. Green MH. Genetics as a historicist discipline: a new player in disease history. Perspectives on History 2014. Available at: http://www.historians.org/publications-and-directories/perspectives-onhistory/december-2014/genetics-as-a-historicist-discipline. Accessed 26 September 2015.

39. Green MH. Taking 'pandemic' seriously: making the Black Death global. The Medieval Globe 2014; 1: $27-62$.

40. Little LK. Plague historians in lab coats. Past and Present 2011; 213: 267-290.

41. Drancourt M, Aboudharam G, Signoli M, Dutour O, Raoult, D. Detection of 400-year-old Yersinia pestis DNA in human dental pulp: an approach to the diagnosis of ancient septicemia. PNAS 1998; 95: 12637 12640.

42. Bos KI, Schuenemann VJ, Golding GB, et al. A draft genome of Yersinia pestis from victims of the Black Death. Nature 2011; 478: 506-10.

43. Cui Y, Yu C, Yan Y, et al. Historical variations in mutation rate in an epidemic pathogen, Yersinia pestis. Proc Natl Acad Sci U S A 2013; 110: 577-82. 
The Lancet Infectious Diseases Published Online August 10, 2016

DOI: http://dx.doi.org/10.1016/S1473-3099(16)30119-0

http://www.thelancet.com/journals/laninf/article/PIIS1473-3099(16)30119-0/fulltext

44. Bos KI, Herbig A, Sahl J, et al. Eighteenth century Yersinia pestis genomes reveal the long-term persistence of an historical plague focus. eLife 2016; 10.7554/eLife.12994

45. Carmichael, AG. Plague persistence in Western Europe: a hypothesis. The Medieval Globe 2014; 1: $157-$ 192.

46. Varlik N. Plague and empire in the modern Mediterranean world: the Ottoman experience, 1347-1600. Cambridge: Cambridge University Press, 2015.

47. Kislichkina AA, Bogun AG, Kadnikova LA, et al. Nineteen whole-genome assemblies of Yersinia pestis subsp. microtus, including representatives of biovars caucasica, talassica, hissarica, altaica, xilingolensis, and ulegeica. Genome Announc 2015; 3: e01342-15.

48. Anisimov AP, Lindler LE, Pier GB. Intraspecific diversity of Yersinia pestis. Clin Microbiol Rev 2004; 17: 434-64.

49. Ayyadurai S, Sebbane F, Raoult D, Drancourt M. 2010. Body lice, Yersinia pestis Orientalis, and Black Death. Emerg Infect Dis 2010; 16: 892-3.

50. Ben-Ari T, Neerinckx S, Gage KL, et al. Plague and climate: scales matter. PLoS Pathogens 2011; 7:e1002160.

51. Crespo F and Lawrenz MB. Heterogeneous immunological landscapes and medieval plague: an invitation to a new dialogue between historians and immunologists. The Medieval Globe 2014; 1: 229-258.

52. DeWitte SN. The anthropology of plague: insights from bioarcheological analyses of epidemic cemeteries. The Medieval Globe 2014; 1: 97-124.

53. Respicio-Kingry LB, Yockey BM, Acayo S, et al. Two distinct Yersinia pestis populations causing plague among humans in the West Nile region of Uganda. PLoS Negl Trop Dis 2016; 10: e0004360.

54. Schuenemann VJ, Singh P, Mendum TA, et al. Genome-wide comparison of medieval and modern Mycobacterium leprae. Science 2013; 341: 179-83.

55. Han XY, Silva, FJ. On the age of leprosy. PLoS Negl Trop Dis 2014; 8: e2544.

56. Foxhall K. Making modern migraine medieval: men of science, Hildegard of Bingen and the life of a retrospective diagnosis. Med Hist 2014; 58: 354-74.

57. Green MH, Jones L, Little, LK, et al. Yersinia pestis and the three plague pandemics. Lancet Infect Dis 2014; 14: 918.

58. Pontius A.A. Icono-diagnosis, a medical-humanistic approach, detecting Crouzon's Malformation in Cook Islands' prehistoric art. Perspect Biol Med 1983; 27: 107-120.

59. Grmek MD, Gourvitch D. Les maladies dans l'art antique. Paris: Fayard, 1998. 